\title{
SNOSP: Ion deposition and concentration in high alpine snow packs
}

\begin{abstract}
By U. NICKUS ${ }^{1, *}$, M. KUHN ${ }^{1}$, U. BALTENSPERGER ${ }^{2}$, R. DELMAS ${ }^{3}$, H. GÄGGELER ${ }^{2}$, A. KASPER ${ }^{4}$, H. KROMP-KOLB ${ }^{5}$, F. MAUPETIT ${ }^{3}$, A. NOVO ${ }^{6}$, F. PICHLMAYER ${ }^{7}$, S. PREUNKERT ${ }^{8}$, H. PUXBAUM ${ }^{4}$, G. ROSSI ${ }^{9}$, W. SCHÖNER ${ }^{10}$, M. SCHWIKOWSKI ${ }^{2}$, P. SEIBERT ${ }^{10}$, M. STAUDINGER ${ }^{11}$, V. TROCKNER ${ }^{12}$, D. WAGENBACH ${ }^{8}$ and W. WINIWARTER ${ }^{7},{ }^{1}$ Institut für Meteorologie und Geophysik, Universität Innsbruck, Innrain 52, A-6020 Innsbruck, Austria; ${ }^{2}$ Paul Scherrer Institut, CH-5232 Villingen, Switzerland; ${ }^{3}$ Laboratoire de Glaciologie et Geophysique de l'Environnement, B.P.96, F-38402 Saint-Martin-d'Hères Cedex, France; ${ }^{4}$ Institut für Analytische Chemie, Universität Wien, Getreidemarkt 9, A-1060 Wien, Austria; ${ }^{5}$ Institut für Meteorologie und Physik, Universität für Bodenkultur, Türkenschanzstr. 18, A-1185 Wien, Austria; ${ }^{6}$ ENEL-CRTN, Via Rubattino 54, I-20134 Milano, Italy, ${ }^{7}$ Österreichisches Forschungszentrum Seibersdorf, A-2444 Seibersdorf, Austria; ${ }^{8}$ Institut für Umweltphysik, Universität Heidelberg, Im Neuenheimer Feld 368, D-69120 Heidelberg, Germany; ${ }^{9}$ ENEL-CRIS, Corso del Popolo 245, I-30172 Venezia Mestre, Italy; ${ }^{10}$ Institut für Meteorologie und Geophysik, Universität Wien, Hohe Warte 38, A-1190 Wien, Austria; ${ }^{11}$ Zentralanstalt für Meteorologie und Geodynamik, Freisalweg 16, A-5020 Salzburg, Austria; ${ }^{12}$ Biologisches Labor, Unterbergstraße 2, I-39055 Leifers, Italy
\end{abstract}

(Manuscript received 18 April 1995; in final form 15 July 1996)

\begin{abstract}
The present paper summarizes the results of SNOSP, a snow sampling program carried out in the Alps in the years from 1991 to 1993 in order to study the chemical composition of the high alpine snow pack. The paper briefly describes the sampling sites and the procedures used, focussing then on the geographical, seasonal and year to year variation of the mean concentration and total deposition of eight major ions, viz., chloride, nitrate, sulfate, ammonium, sodium, potassium, magnesium and calcium. $\mathrm{NH}_{4}^{+}, \mathrm{NO}_{3}^{-}$and $\mathrm{SO}_{4}^{-}$concentrations in spring snow are higher by a factor of two to three than in winter snow since the lower tropospheric convection is confined to the valleys in winter and extends beyond glacier altitudes in spring. This underlines the importance of local and regional versus long range transport of contamination to the high elevated sites. The $\mathrm{Ca}^{++}$deposition occurs in single events (e.g., dust input from the Sahara) with a slightly higher incidence in spring that is consistent with the annual course of atmospheric circulation patterns. Most ionic species display a west to east increase of concentration by about one third. The prevailing precipitation patterns have opposite gradients so that total ionic load of the respective snowpack has no regional preference. The seasonal contrast as expressed by ratios of spring to winter concentrations of $\mathrm{NH}_{4}^{+}, \mathrm{NO}_{3}^{-}$and $\mathrm{SO}_{4}^{-}$is stronger in the west than in the east, and the east to west contrast is greater in winter than in spring.
\end{abstract}

\section{Introduction}

In order to investigate the input of pollutants and trace substances and their respective effects

\footnotetext{
* Corresponding author.

e-mail: ulrike.nickus@uibk.ac.at.
}

on ecosystems, several projects were initiated in central Europe in the eighties. Most of them operated at low elevations and only a few investigations were dedicated to the impact of anthropogenic pollutants at high altitudes.

In the Alps, the amount of deposited substances was derived from the chemical analysis of snow 
samples (Neftel et al., 1987; Psenner and Nickus, 1986; Ronseaux and Delmas, 1988; Wagenbach et al., 1988). In spite of the lower pollutant concentrations at high alpine compared to valley stations, the deposited loads of substances ranged in the same order of magnitude both at glaciers and in the valleys due to the general increase of precipitation with height. Mineral dust has a strong influence on the chemistry of a snowpack. Depending on the amount deposited, dust may partially or even totally neutralize the acidity accumulated in the snowcover (Psenner and Nickus, 1986).

An investigation of high mountain lakes in the Austrian Alps showed that these sensitive ecosystems run the risk of being acidified due to an increased input of acid substances of anthropogenic origin. Psenner et al. (1988) had found that $21 \%$ of them already lay below the critical value of $\mathrm{pH}$ 6. The effect of acid deposition on aquatic and terrestrial ecosystems strongly depends on the occurrence and developement of snowmelt - the high pollutant concentrations of the first meltwater fractions (Johannessen and Henriksen, 1978) may cause an "acid shock" in lakes and rivers.

An increasing input of trace substances due to anthropogenic activities could also be seen from ice cores drilled at cold glaciers in the Alps. At Colle Gnifetti (Monte Rosa, $4450 \mathrm{~m}$ a.s.l.) the mean concentrations of sulfate and nitrate have increased by a factor of 4 to 5 during the last 100 years (Wagenbach et al., 1988).

In 1990, a new project, called ALPTRAC, was initiated (Puxbaum, 1990). Subdivided into 4 parts the following objectives were to be investigated: (i) the amount of deposited trace substances (acidifying and neutralizing compounds and selected tracers) and its geographical and seasonal variability within the high alpine region (SNOSP); (ii) the main physical and chemical processes responsible for the occurrence of trace substances and the interrelation of alpine air, cloud and snow chemistry (ALASS); (iii) the relative contributions of anthropogenic and natural sources and the respective source regions (SNOWMET); (iv) pollution trends during the past ten decades derived from ice cores (CORE)

In SNOSP, up to 17 sites (the number of sampled sites varied from year to year) at glaciers from the southwestern end of the French Alps to the eastern part of the Austrian Alps have been sampled and analysed for nine major ions in March and May of the years from 1990 to 1994. This paper will focus on the results of SNOSP summarizing the situation in the three years from 1991 to 1993 where most of the sites have been active.

\section{The sampling sites}

The sampling sites had to meet several requirements: They should primarily be representative of background situations remote from local or regional anthropogenic sources. The amount of precipitation at the sampling sites should be representative of the respective area and not influenced by avalanches or frequent snow drift causing either additional accumulation or ablation. Sampling sites should be situated at heights of at least $3000 \mathrm{~m}$ a.s.l. in order to guarantee the onset of snowmelt not before May (a determination of deposited pollutant loads by means of snow sampling is only possible as long as no meltwater has percolated the snowpack). Geographically sampling sites were supposed to cover both the spine of the Alps from southwest to northeast and meridional transects from north to south. But reasons like accessibility of a site or limited manpower and financial facilities restricted the number of possible sites.

Each sampling site was selected by the respective working group according to its local knowledge of the sampling area and experience derived from previous investigations. All sites selected for SNOSP are summarized in Fig. 1. A detailed discription of the individual sites consisting of logistic information, maps, photographs, climatological data, etc. is given in Kromp-Kolb et al. (1993).

From the geographical point of view, the stations may be subdivided into 4 groups. The 1st one in the French Alps (with La Grave (1), Alpe d' Huez (2), Tignes (3) and Chamonix (4)) where precipitation is abundant compared to the Eastern Alps. Water equivalents of the respective snowpacks were on an average about twice as high as those of the eastern sites (group 3) (Table 2). The second group combines the sites in the Monte Rosa region (Breithorn Plateau (5), Theodul Glacier (6), Gornergrat (7), Stockhorn (8) and Colle Vincent (9)) with that on Jungfraujoch (10). 


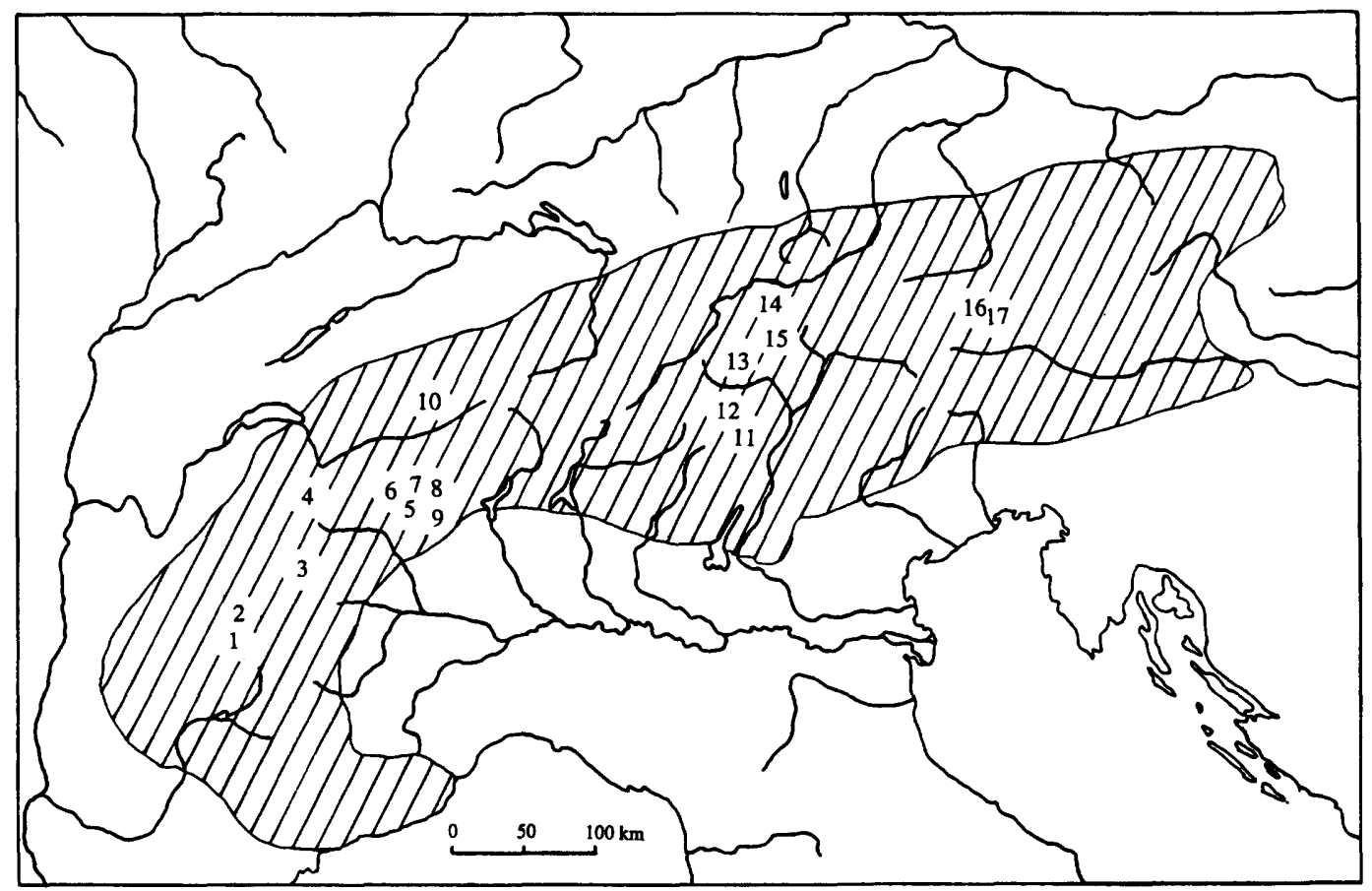

Fig. 1. SNOSP sampling sites.

1. La Grave ( $3360 \mathrm{~m}$, Ecrins, France)

2. Alpe d'Huez ( $3310 \mathrm{~m}$, Grandes Rousses, France)

3. Tignes ( $2980 \mathrm{~m}$, Vanoise, France)

4. Chamonix ( $3540 \mathrm{~m}$, Mont Blanc, France)

5. Breithorn Plateau ( $3900 \mathrm{~m}$, Monte Rosa, Switzerland)

6. Theodul Glacier ( $3200 \mathrm{~m}$, Monte Rosa, Switzerland)

7. Gornergrat ( $2910 \mathrm{~m}$, Monte Rosa, Switzerland)

8. Stockhorn ( $3470 \mathrm{~m}$, Monte Rosa, Switzerland)

9. Colle Vincent ( $4086 \mathrm{~m}$, Monte Rosa, Italy)

10. Jungfraujoch ( $3450 \mathrm{~m}$, Berner Alps, Switzerland)

11. Careser ( $3090 \mathrm{~m}$, Ortles-Cevedale, Italy)

12. Laaser Ferner ( $3250 \mathrm{~m}$, Ortles, Italy)

13. Hintereisferner ( $3100 \mathrm{~m}$, Ötztal Alps, Austria)

14. Griesferner ( $3000 \mathrm{~m}$, Stubai Alps, Austria)

15. Daunferner ( $2960 \mathrm{~m}$, Stubai Alps, Austria)

16. Goldbergkees ( $3080 \mathrm{~m}$, Hohe Tauern, Austria)

17. Wurtenkees ( $3050 \mathrm{~m}$, Hohe Tauern, Austria)

This group has both the highest absolute and average elevation with about $3500 \mathrm{~m}$ a.s.l. Precipitation increases from south to north of the main ridge of the Alps, which also applies to the 3rd group (Careser (11), Laaser Ferner (12), Hintereisferner (13), Griesferner (14), Daunferner (15)). The 4th group comprises 2 of the easternmost Austrian glaciers (Goldbergkees (16) and Wurtenkees (17)). The sites of the 2 nd and the 4th groups have the advantage of being situated close to the year-round observatories at Jungfraujoch and Sonnblick, respectively.

\section{Sampling, analysis and quality check}

SNOSP offered for the first time the possibility to perform snow sampling campaigns almost sim- 
ultaneously at up to 17 glaciers in the Alps by similar sampling techniques and procedures in order to study the geographical, interannual and seasonal variability of the pollutant impact in the Alps.

The sampling procedure that was adhered to by all participating teams had evolved from the experiences of individual groups in the previous years. Snow pits of up to several meters were dug at the selected sites, normally down to the summer horizon of the previous year and snow samples were taken along a vertical profile usually at intervals of $10 \mathrm{~cm}$. At Jungfraujoch and at the French sites snow cores were drilled instead of digging a pit and cores were cut into pieces of $10 \mathrm{~cm}$. Density and stratigraphy were recorded with particular attention to dust and ice layers.

In view of the extremely low ion concentrations that were to be expected, a number of precautions was mandatory for sampling and analytical procedure. Any material assumed to come into contact with the sampled snow (like bottles, bags, shovels, vials, etc.) had to be carefully cleaned in the laboratories before. During sampling nonfibrous clothing, nose and mouth masks and rubber gloves were worn by the operators. Samples were kept frozen until analysis to avoid changes in the sample liquid, like bacteria growth and chemical reactions (Schwikowski et al., 1996).

The seasonal variation of pollutant impact was derived by sampling twice a winter half year, preferably in early March and in May. However, due to practical limitations sampling times varied up to four weeks for individual sites.

Major ions (nitrate, sulfate, ammonium, chloride, sodium, potassium,magnesium and calcium) were measured by all groups, whereas parameters like $\mathrm{pH}$, alkalinity/acidity and conductivity were determined only by some of them. Ion chromatography was the most frequently applied analytical method. Flame emission spectroscopy or inductively coupled plasma optical emission spectrometry were used for cation analysis in some instances. Conductivity, $\mathrm{pH}$ and alkalinity were generally determined by potentiometry (Schwikowski et al., 1996).

It would go beyond the scope of this paper to discuss parameters like detection limits or laboratory and field blanks of all analytical methods used by the individual groups. Maupetit et al. (1994), for instance, reported a precision of 5 to $10 \%$ for their measurements with ion chromatography and a precision of 10 to $30 \%$ for the determination of $\mathrm{H}^{+}$, a titration method based on Gran's plot method. Detection limits between 0.01 and $0.08 \mu \mathrm{eq} / 1$ were found by Nickus and Kuhn (1994) for the detection of ions with ion exchange chromatography. Only for sodium was the detection limit higher due to a laboratory blank of $0.1 \mu \mathrm{eq} / 1$.

The comparability of sampling and analytical methods of the individual groups was checked by means of round robin tests and two intercomparisons, performed in the framework of SNOSP (Schwikowski et al., 1996). In artificial snow samples the relative standard deviation of measured ion concentrations ranged between 3 and $17 \%$ for anions, ammonium, sodium and calcium, but was up to four times higher for magnesium and potassium. These high values were due to the increased relative importance of analytical errors for low concentrations. For real snow samples, taken in one snow pit within a horizontal distance of about $3 \mathrm{~m}$, similar results for the relative standard deviation of ion concentrations were found. The high relative standard deviation of about $40 \%$, that was found for calcium, too, was caused by its high local variability in deposition.

This natural local variability of ion concentrations in snow was investigated at Daunferner for sulfate, nitrate and chloride (Nickus and Kuhn, 1993). Samples were taken from a well defined layer of fresh snow at distances of $10 \mathrm{~cm}$, respectively. The relative standard deviation amounted to about $12 \%$ for sulfate and $17 \%$ for nitrate. It was higher for chloride which was, however, close to its detection limit.

The coefficient of variation decreased by one order of magnitude for the mean sulfate, nitrate and chloride concentrations of the entire snowpack, when samples were taken along three parallel, vertical profiles inside one snowpit (Schöner et al., 1996), but it ranged again between 10 and $20 \%$, when the snowpack was sampled at distances of up to $500 \mathrm{~m}$.

\section{Results and discussion}

Before discussing the results of SNOSP some preliminary comments should be made on the existing data set. In spite of standardized sampling procedures and analytical intercomparisons data 
turned out not to be as homogenous as one might expect. Apart from the different conditions of elevation, precipitation, regional and local emission sources, single deposition events (e.g. mineral dust fall), etc. for each site, sampling times varied between all sites and years due to the individual weather conditions. All these facts put certain restrictions on an interpretation of the data set, one should keep in mind for the following discussion of the results.

\subsection{Regional distribution}

The results of the sampling campaigns in 1991, 1992 and 1993 are summarized in Table 1 and 2. Ion concentrations are mean values for the total snowpack (including layers with extremely high concentrations or mineral dust), weighted with the water equivalent of the respective snow layer. Values given in Table 1 and 2 were calculated by the individual working groups, which also decided to eventually exclude data from the set, if melting processes had already caused a release of trace substances from the snow pack before sampling (e.g. for Griesferner and Hintereisferner in May 1992).

Ion concentrations were generally higher in the eastern part of the Alps than in the west (Table 1). However, differences were not very pronounced and varied considerably within the years 1991 to 1993.

For nitrate, sulfate and ammonium the west to east increase in weighted mean concentrations ranged between 2 and $5 \mu \mathrm{eq} / 1$ (Fig. 2, 3). Concurrently the relative contribution of nitrate increased in the same sense as is seen in the group averages of Table 3 where the nitrate to sulfate ratio nearly doubled from group 1 (west) to group 4 (east).

The distribution of mean concentrations between the western and eastern sites was reversed for calcium with the higher values in the west (Table 3, Fig. 3). However, due to the high episodic character of Saharan dust events, the most important source for calcium input to a snow cover, mean concentrations varied from $1 \mu \mathrm{eq} / 1$ up to $37 \mu \mathrm{eq} / 1$ between the individual sites and years (Table 1).

Concentrations of potassium and magnesium were generally low with mean values of $1 \mu \mathrm{eq} / 1$ or less. Exceptionally high concentrations of magnes- ium were always correlated to high calcium concentrations, both of which originate mainly from the input of mineral dust. A slight increase of concentrations from the Western Alps to the east was also found for chloride and sodium (Table 1). There was a generally close relation between both compounds suggesting their origin to an overwhelming extent from the sea salt aerosol. As for magnesium higher sodium and chloride concentrations may be related to dust events. Similarly, the ratio of chloride to sodium increased from west to east. At the western sites it was close to the value of 1.16 for sea water (Wilson 1975) while it was about twice as high at the eastern sites. We follow Maupetit et al. (1994) in assuming that this difference is due to the lesser $\mathrm{HCl}$ input in the Western Alps.

The distribution of nitrate, sulfate and calcium within the Alps with its west to east increase of nitrate and sulfate and east to west increase of calcium were confirmed by the distribution of $\mathrm{H}^{+}$ concentrations in snow. All sites showed a slightly acid snow cover with mean $\mathrm{H}^{+}$concentrations in the west remaining well below $8 \mu \mathrm{eq} / 1$ and ranging between 5 and $15 \mu \mathrm{eq} / 1$ in the east (no values were given for the French and the two easternmost Austrian sites).

The regional distribution of ion concentrations combined with the precipitation pattern result in the regional distribution of ionic loads. Generally, precipitation (expressed by the water equivalent of a snow cover) showed an east to west increase within the Alps and thus smoothed the differences in mean ion concentrations for most ionic species (Table 2), so that no regional preference was found for ionic loads.

\subsection{Seasonal trends and vertical profiles}

At most of the SNOSP sites, a characteristic seasonal course with a winter minimum is observed in the concentration of ions in snow that is preserved in a vertical sequence as long as the snowpack remains cold. Generally, there are higher concentrations in the first snow falls of late summer and autumn. Winter has low values and high variability both of individual ions and of their respective ratios. In spring concentrations rapidly increase to reach a maximum, normally in April, comparable to that of fall (Puxbaum et al., 1991; Maupetit and Delmas, 1994). This strong 
Table 1. Weighted mean ion concentrations ( $\mu$ eq/l) of the snow cover at the individual sites in 1991, 1992 and 1993

\begin{tabular}{|c|c|c|c|c|c|c|c|c|c|c|c|c|c|c|c|c|c|c|c|c|c|c|c|c|c|c|c|c|c|}
\hline \multirow[b]{2}{*}{ Group } & & & \multicolumn{3}{|c|}{$\mathrm{Cl}^{-}$} & \multicolumn{3}{|c|}{$\mathrm{NO}_{3}^{-}$} & \multicolumn{3}{|c|}{$\mathrm{SO}_{4}^{z}$} & \multicolumn{3}{|c|}{$\mathrm{Na}^{+}$} & \multicolumn{3}{|c|}{$\mathrm{NH}_{4}^{+}$} & \multicolumn{3}{|c|}{$\mathbf{K}^{+}$} & \multicolumn{3}{|c|}{$\mathrm{Mg}^{++}$} & \multicolumn{3}{|c|}{$\mathrm{Ca}^{++}$} & \multicolumn{3}{|c|}{$\mathrm{H}^{+}$} \\
\hline & & & 1991 & 1992 & 1993 & 1991 & 1992 & 1993 & 1991 & 1992 & 1993 & 1991 & 1992 & 1993 & 1991 & 1992 & 1993 & 1991 & 1992 & 1993 & 1991 & 1992 & 1993 & 1991 & 1992 & 1993 & 1991 & 1992 & 1993 \\
\hline \multirow{8}{*}{ I } & La Grave & III & 0.7 & 0.7 & $*$ & 3.2 & 2.8 & * & 3.9 & 3.8 & * & 0.4 & 0.5 & * & 1.1 & 1.5 & $*$ & 0.1 & 0.1 & * & 0.2 & 0.4 & * & 2.9 & 3.4 & 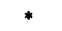 & ${ }^{*}$ & ${ }^{*}$ & ${ }^{*}$ \\
\hline & & $\mathrm{v}$ & 1.4 & 1.2 & * & 5.1 & 3.1 & * & 10.5 & 4.1 & * & 1.3 & 0.9 & * & 4.1 & 2.7 & . & 0.3 & 0.4 & * & 0.8 & 0.6 & . & 12.1 & 5.0 & * & * & * & * \\
\hline & Alpè d'Huez & III & * & * & * & $*$ & $*$ & * & $*$ & $*$ & * & * & $*$ & * & * & * & * & ${ }^{*}$ & * & * & $*$ & $*$ & * & $*$ & $*$ & * & * & * & * \\
\hline & & $\mathrm{V}$ & 1.7 & * & * & 3.1 & * & * & 7.2 & * & * & 1.7 & * & * & 2.5 & * & * & 0.4 & * & * & 0.5 & * & * & 5.2 & * & * & * & * & * \\
\hline & Tignes & III & * & * & * & $*$ & * & * & $*$ & * & * & $\ldots$ & * & * & $*$ & * & * & $*$ & * & $*$ & $*$ & $*$ & * & $*$ & * & * & * & * & * \\
\hline & & $\mathrm{V}$ & 1.2 & * & * & 6.0 & * & * & 7.9 & * & * & 0.8 & * & * & 4.0 & * & * & 0.3 & * & * & 0.9 & * & * & 5.6 & * & * & * & $*$ & * \\
\hline & Chamonix & III & $*$ & * & * & $*$ & * & * & $*$ & * & * & $*$ & * & * & $*$ & * & * & $*$ & * & * & $*$ & $*$ & * & $*$ & * & * & * & * & * \\
\hline & & $\mathrm{V}$ & 1.0 & 1.5 & * & 6.0 & 2.9 & * & 8.2 & 3.2 & * & 0.6 & 1.0 & * & 4.1 & 3.1 & $*$ & 0.3 & 0.5 & * & 0.4 & 0.4 & $*$ & 3.4 & 1.7 & * & * & * & $*$ \\
\hline \multirow{9}{*}{ II } & Breithorn & III & 0.9 & 0.3 & 0.6 & 4.6 & 2.7 & 3.0 & 4.4 & 4.3 & 3.3 & 0.5 & 0.7 & 0.3 & 3.4 & 1.2 & 1.7 & 0.2 & 0.1 & 0.1 & * & * & * & 3.9 & 4.1 & 4.1 & * & * & * \\
\hline & & $\mathrm{V}$ & 1.1 & 0.6 & 1.8 & 6.7 & 3.8 & 5.2 & 5.1 & 5.4 & 11.1 & 0.5 & 0.8 & 1.9 & 3.9 & 2.0 & 6.0 & 0.3 & 0.1 & & * & * & * & 5.3 & 3.4 & 19.0 & * & * & * \\
\hline & Gornergrat & III & 0.9 & 1.8 & 0.7 & 5.1 & 4.7 & 3.8 & 6.6 & 4.4 & 5,4 & 0.7 & 1.8 & 0.6 & 3.2 & 1.1 & 1.9 & 0.3 & 0.5 & 0.2 & * & * & * & 10.7 & 10.3 & 5.6 & * & * & * \\
\hline & Gorner + Theo & $\mathrm{V}$ & 1.0 & 1.5 & 1.3 & 14.7 & 5.4 & 5.9 & 11.1 & 6.5 & 9.5 & 0.8 & 1.5 & 0.8 & 6.1 & 2.7 & 5.1 & 0.5 & 0.4 & 0.1 & * & $*$ & 9.5 & 8.2 & 8.6 & 8.0 & * & * & * \\
\hline & Stockhorn & III & $*$ & $\begin{array}{c}0.3 \\
*\end{array}$ & 0.6 & $*$ & 2.1 & 3.8 & $*$ & $\stackrel{2.1}{*}$ & 3.1 & * & 0.5 & 0.4 & $*$ & 0.6 & 0.5 & $*$ & 0.1 & 0.1 & $*$ & $*$ & $*$ & $*$ & 2.6 & 1.2 & * & * & $*$ \\
\hline & Colle Vincent & III & * & * & 1.0 & * & $*$ & 7.3 & * & $*$ & 10.7 & * & * & 0.7 & * & * & 8.8 & * & * & 0.1 & * & * & 0.8 & * & $*$ & 38 & $*$ & * & * \\
\hline & & $\mathrm{v}$ & $*$ & 0.7 & 1.2 & * & 5.0 & 4.8 & * & 7.6 & 15.1 & $*$ & 0.6 & 0.1 & * & 3.2 & $\begin{array}{l}.0 .0 \\
9.1\end{array}$ & * & 0.3 & 0.4 & * & 0.4 & $\begin{array}{l}.0 \\
1.3\end{array}$ & $*$ & 2.4 & $\begin{array}{c}3.0 \\
14.3\end{array}$ & * & * & $*$ \\
\hline & Jungfraujoch & III & 1.5 & 1.6 & 0.8 & 4.6 & 3.0 & 3.6 & 4.1 & 4.5 & 4.9 & 1.8 & 1.0 & 0.7 & 1.1 & 1.1 & 1.9 & 1.2 & 0.7 & 0.2 & 2.0 & 2.1 & 0.9 & 21.3 & 36.5 & 12.6 & 2.1 & 1.3 & 3.7 \\
\hline & & V & 1.4 & 1.6 & 0.8 & 9.5 & 4.0 & 3.4 & 10.4 & 5.2 & 5.2 & 1.5 & 0.9 & 0.6 & 5.5 & 2.8 & 2.1 & 0.9 & 0.7 & 0.2 & 1.8 & 1.9 & 0.9 & 13.2 & 30.8 & 11.6 & 5.9 & 1.7 & 3.7 \\
\hline \multirow{10}{*}{ III } & Careser & III & 2.0 & 0.6 & 0.8 & 4.0 & 4.9 & 6.3 & 9.2 & 5.1 & 4.5 & 4.2 & 0 & 0.3 & 30 & 2.3 & 4.2 & 0 & 04 & 0.1 & 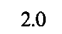 & 10 & 0.5 & 89 & 25 & 20 & * & * & * \\
\hline & & V & 3. & 0.9 & $*$ & 7 & 6. & * & 16.2 & 5. & 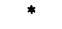 & 10.2 & 0. & * & 5.0 & 4. & * & 0.8 & 0.5 & $*$ & 4.1 & 1. & * & 13.9 & U & * & * & * & * \\
\hline & Laaser $F$. & III & 3.9 & 1.0 & * & 4.3 & 4. & * & 6.6 & 5 & * & 3.8 & 0. & * & 2.7 & 2 & $*$ & 1.9 & 0.4 & * & 2.1 & 0.9 & * & 14.4 & 5.2 & * & 4.6 & 4.2 & * \\
\hline & & $\mathrm{V}$ & 4.0 & 4.2 & * & 8.5 & 6.2 & * & 7.9 & 6.0 & * & 3.4 & 2.9 & * & 5.2 & 3.7 & $*$ & 1.2 & 0.9 & * & 1.5 & 0.5 & * & 8.4 & 5.6 & * & 8.9 & 6.0 & * \\
\hline & Hintereisf. & III & 3.5 & 0.9 & 1.3 & 6.1 & 4.6 & 7.1 & 6.2 & 5.2 & 5.6 & 1.3 & 1.0 & 0.8 & 2.7 & 4.3 & 2.8 & 0.4 & 0.5 & 0.3 & 1.2 & 0.7 & 0.3 & 4.7 & 3.5 & 2.0 & 10.1 & 6.0 & 10.0 \\
\hline & & $\mathrm{V}$ & 2.8 & $*$ & 1.2 & 13.9 & * & 5.3 & 13.1 & * & 6.4 & 1.7 & $*$ & 0.9 & 9.8 & $*$ & 4.5 & 1.1 & $*$ & 0.2 & 1.7 & $*$ & 0.5 & 12.0 & $*$ & 2.3 & 22.4 & $*$ & 7.9 \\
\hline & Griesferner & III & 3.1 & 1.3 & 1.2 & 6.2 & 3.6 & 6.9 & 3.3 & 2.8 & 3.9 & 1.3 & 0.4 & 0.6 & 1.2 & 1.0 & 1.6 & 0.6 & 0.1 & 0.0 & 0.5 & 0.4 & 0.2 & 1.2 & 1.2 & 0.6 & 11.4 & 7.6 & 12.6 \\
\hline & & V & 3.2 & * & 1.3 & 10.3 & * & 5.8 & 7.7 & $*$ & 3.8 & 0.9 & * & 0.8 & 5.4 & * & 2.3 & 0.3 & * & 0.1 & 0.8 & * & 0.4 & 3.1 & * & 1.2 & 15.7 & $*$ & 10.2 \\
\hline & Daunferner & III & $*$ & * & 1.1 & $*$ & * & 8.9 & $*$ & $*$ & 5.2 & $*$ & * & 0.5 & $*$ & * & 4.5 & * & $*$ & 0.1 & $*$ & * & 0.3 & $*$ & * & 1.0 & $*$ & * & 13.8 \\
\hline & & $\mathrm{v}$ & * & * & 1.2 & * & * & 9.1 & * & * & 5.4 & * & * & 0.7 & * & * & 4.6 & $*$ & * & 0.2 & * & * & 0.2 & * & $*$ & 1.1 & * & * & 10.7 \\
\hline \multirow{4}{*}{ IV } & Goldbergk. & III & 5.6 & 3.1 & 1.4 & 11.0 & 10.5 & 7.8 & 6.9 & 7.7 & 8.3 & 5.6 & 3.2 & 1.2 & 4.3 & 4.4 & 4.1 & 1.9 & 0.1 & 0.2 & 1.9 & 2.5 & 1.2 & 4.3 & 7.4 & 2.7 & * & * & * \\
\hline & & $\mathrm{v}$ & 2.1 & 2.7 & 1.3 & 11.4 & 9.0 & 11.8 & 9.3 & 8.3 & 11.9 & 3.7 & 3.1 & 1.0 & 7.1 & 4.7 & 8.6 & 0.7 & 0.4 & 0.1 & 1.9 & 2.4 & 2.1 & 6.4 & 6.4 & 6.0 & * & * & 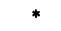 \\
\hline & Wurtenkees & III & * & * & * & $*$ & $*$ & $*$ & * & $*$ & $*$ & $*$ & * & * & * & * & * & $*$ & $*$ & $*$ & 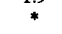 & $*$ & $*$ & $*$ & $*$ & $*$ & * & * & * \\
\hline & & $\mathrm{v}$ & 4.1 & 5.2 & 1.7 & 8.1 & 9.4 & 9.4 & 7.8 & 8.3 & 8.7 & 4.0 & 5.2 & 1.3 & 6.7 & 5.0 & 7.0 & 1.7 & 0.6 & 0.2 & 2.1 & 1.1 & 2.2 & 3.4 & 5.0 & 7.2 & * & * & * \\
\hline
\end{tabular}

III sampling in March or April, $\mathrm{V}$ sampling at the end of the accumulation period, ${ }^{*}$ no data. $\left(\mathrm{H}^{+}\right.$as given by the individual groups, e.g., calculated from $\mathrm{pH}$ measurements) 
Table 2. Ionic loads $\left(\mathrm{meq} / \mathrm{m}^{2}\right)$ and water equivalent ( $\mathrm{cm}$ ) of the snow cover at the individual sites in 1991, 1992 and 1993

\begin{tabular}{|c|c|c|c|c|c|c|c|c|c|c|c|c|c|c|c|c|c|c|c|c|c|c|c|c|c|c|c|c|c|c|c|c|}
\hline \multirow{2}{*}{ Group } & & & \multicolumn{3}{|c|}{$\mathrm{Cl}^{-}$} & \multicolumn{3}{|c|}{$\mathrm{NO}_{3}^{-}$} & \multicolumn{3}{|c|}{$\mathrm{SO}_{4}^{\bar{\prime}}$} & \multicolumn{3}{|c|}{$\mathrm{Na}^{+}$} & \multicolumn{3}{|c|}{$\mathrm{NH}_{4}^{+}$} & \multicolumn{3}{|c|}{$\mathrm{K}^{+}$} & \multicolumn{3}{|c|}{$\mathrm{Mg}^{++}$} & \multicolumn{3}{|c|}{$\mathrm{Ca}^{++}$} & \multicolumn{3}{|c|}{$\mathrm{H}^{+}$} & \multicolumn{3}{|c|}{ W.E. $(\mathrm{cm})$} \\
\hline & & & 1991 & 19921 & 19931 & 1991 & 1992 & 1993 & 1991 & 19921 & 1993 & 1991 & 1992 & 1993 & 1991 & 1992 & 1993 & 1991 & 1992 & 1993 & 1991 & 1992 & 1993 & 1991 & 19921 & 19931 & 1991 & 1992 & 1993 & 1991 & 1992 & 1993 \\
\hline & La Grave & II & 0. & 0.7 & & 2.7 & 2.8 & & 3.3 & 3. & & 0.3 & 0.5 & & 0.9 & 16 & & 0.1 & 0.2 & * & 0.2 & 0.4 & & .5 & 3.4 & * & & * & ${ }^{*}$ & 86 & 02 & * \\
\hline & Alpè d'H & III & $\begin{array}{c}2.7 \\
*\end{array}$ & $*$ & . & $\begin{array}{l}9.9 \\
*\end{array}$ & 5.4 & * & $\stackrel{20.4}{*}$ & ${ }_{*}^{*}$ & * & $*$ & $*$ & * & $*$ & $*$ & * & ${ }_{*}^{0.7}$ & & $*$ & 1.5 & $*$ & ** & 3.6 & * & & & * & & * & * 75 & ${ }^{*}$ \\
\hline & & $\mathrm{v}$ & 2.6 & 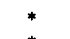 & $*$ & 4.6 & * & & 10.9 & * & & 2.6 & 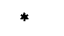 & * & 3.7 & 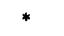 & t & 0.7 & & 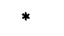 & 0.7 & $*$ & 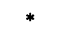 & 7.7 & 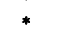 & * & & * & & 150 & 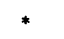 & * \\
\hline & Tign & II & ${ }_{1.8}^{*}$ & * & $*$ & 9.0 & ** & * & $\stackrel{*}{*}$ & * & & * & * & ** & 6.0 & * & ** & 0.4 & * & * & 4 & * & ** & 8.4 & ** & & & ** & * & ${ }_{150}^{*}$ & * & * \\
\hline & Chamonix & III & $*$ & * & * & & * & * & & * & * & & * & * & & * & * & & * & & & * & & . & * & & & $*$ & & & 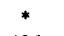 & 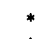 \\
\hline & & & 2.0 & 2.9 & 03 & 11.0 & 5.7 & 3 & 16.0 & 6.4 & 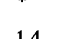 & 1.1 & 1.9 & * & 7.9 & 60 & * & 05 & 0.9 & & .7 & 0.8 & * & 6.7 & 3.4 & ${ }^{*}$ & s. & * & * & 195 & 196 & ${ }^{*}$ \\
\hline & & & & 0.4 & 0. & & 2. & & 4.8 & 3.1 & & 0.4 & & 1.7 & & & 5.3 & & & & & & * & 5.0 & 2.01 & 16.7 & 9 & & 0.0 & $\begin{array}{l}70 \\
95\end{array}$ & 37 & 42 \\
\hline & & II & 0.4 & 0.8 & 0.3 & 2.2 & 2. & 1.5 & 3. & 1.9 & 2. & 0.3 & 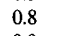 & 0.2 & 5 & 0.5 & 0.8 & 2 & 0.2 & & & & & 4.9 & 4.5 & 2.2 & .4 & & 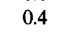 & 46 & 44 & +0 \\
\hline & & & 0.8 & 0.9 & 1.41 & 11.6 & & 6.1 & 8.8 & 4.1 & & 0.6 & 0.9 & 0.8 & & 1.7 & 5.3 & 4 & 0.3 & & & & & 6.4 & 5.4 & 9.8 & 9.2 & & 0.0 & 79 & 3 & 103 \\
\hline & Sto & III & * & 0.1 & 0.2 & * & 0.9 & 1.2 & * * & 0.9 & 1.0 & ** & 0.2 & 0.1 & * & 0.2 & 0.2 & * & 0.1 & $*$ & * & * & ** & * & 1.1 & 0.4 & * & 0.0 & 1.6 & * & 20 & 32 \\
\hline & & III & * & $*$ & 0.5 & $*$ & * & 3.3 & * & & 4.9 & $x^{\prime}$ & & 0.3 & * & & & & & & & & 0.4 & is & & & & ${ }^{*}$ & & & * & 46 \\
\hline & & & & & 1.3 & 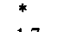 & & & 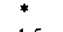 & 6.21 & 15.9 & $*$ & 0. & & ${ }^{*}$ & & & $*$ & 3 & & * & 4 & & * & 2.01 & 15.0 & & * & & & 82 & 05 \\
\hline & Jungfraujoch & III & 0.5 & 2.8 & 1.4 & 1.7 & 5.3 & 6.0 & 1.5 & 8.0 & 8.2 & 07 & & 1 & & & & & & & 8 & & & 7.9 & 65.12 & 21.1 & 8 & & 6.2 & 37 & 8 & 68 \\
\hline & & & & 4.2 & & & 10.4 & 6.7 & 10.5 & $13.5 \quad 1$ & & 1.5 & 2. & 1.2 & 5.6 & 7.4 & 4.2 & 0.9 & 1.9 & 0.5 & 8 & 4.8 & & 13.4 & 79.92 & 23.0 & 6.0 & 4 & 7.4 & 101 & 260 & 198 \\
\hline & Careser & II & 1. & 0.3 & 0.6 & 3.2 & 2.2 & 4 & $\begin{array}{r}7.3 \\
17.5\end{array}$ & $\begin{array}{l}2.3 \\
4.8\end{array}$ & 3.8 & 3.3 & 0.2 & 0.3 & 2.4 & 1.0 & 3.5 & 0.5 & 0.2 & 0.1 & 1.6 & 0.5 & 0.4 & 1.1 & .1 & 2.4 & & ** & * & 80 & 45 & 85 \\
\hline & Laaser $\mathrm{F}$ & 1 & 1. & 0. & * & & 2 & * & 2. & & * & 1. & & ${ }^{*}$ & & & $*$ & & & * & & & & & & * & & .5 & * & & & ${ }^{*}$ \\
\hline & & & & 3.1 & * & & & & 6. & 4.5 & * & 2 & & 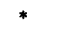 & & & & & & * & & 0. & * & 3 & .2 & * & & 4.5 & $*$ & 76 & 74 & $*$ \\
\hline & Hintereisf & II & 2. & 1.0 & 1.7 & 4.5 & 5. & 9.1 & 7. & 5.8 & 7.1 & & 1.1 & 1.0 & & 4.0 & 3.6 & & 0.6 & 4 & & 0.8 & 4 & 4 & 3.9 & 6 & 4 & 6. $)$ & 12.6 & 73 & 112 & 127 \\
\hline & & & & ${ }^{*}$ & 1.6 & 192 & & & 18. & $*$ & & & $*$ & 12 & & $*$ & 6 & & & & & & & 6.6 & 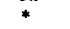 & 3 & & $*$ & 0 & 38 & $*$ & 137 \\
\hline & Griesferner & I & 1. & 1.1 & 1.0 & & 3. & & 28 & 2.4 & & & 0.4 & & & 0.8 & & & $0.1 .2-$ & & & 0.3 & & 0.8 & 0.9 & 5 & 0 & 6.8 & & 62 & 89 & 85 \\
\hline & & & 3.0 & & 1.3 & 11.6 & * & & 8. & & 3.8 & & & & 6.1 & & 2. & 0.3 & & 0.1 & 0.9 & & & 3.5 & * & 1.2 & 17.7 & * & 0.3 & 113 & ${ }^{*}$ & 100 \\
\hline & Daunferner & II & & * & 1. & & * & & * & * & & & * & & & * & & & * & & & 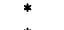 & & & * & & & * & & & * & 113 \\
\hline & & $\mathrm{v}$ & * & * & 1.2 & * & * & 9.1 & * & * & 5.3 & ${ }^{*}$ & * & 0. & * & * & 4. & * & * & 0.2 & * & ${ }^{*}$ & 0.3 & * & * & 1.0 & & * & 13.0 & & * & 122 \\
\hline & Goldbergk. & III & 3.6 & 4.1 & 1.1 & 7.0 & 13.8 & 5.8 & 4.4 & 10.2 & 6.2 & 3.6 & 4.2 & 0.9 & 2.8 & 5.8 & 3.1 & 1.2 & 0.1 & 0.1 & 1.2 & 3.3 & 0.9 & 2.8 & 9.8 & 2.0 & * & * & ${ }^{*}{ }^{*}$ & 64 & 131 & 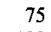 \\
\hline & Wurtenkees & V & 2.2 & *.4 & 1.7 & 11.8 & $\begin{array}{l}14.6 \\
*\end{array}$ & 15.4 & 9.6 & $\begin{array}{c}13.5 \\
*\end{array}$ & $\begin{array}{c}15.5 \\
*\end{array}$ & 3.9 & 4.9 & 1.3 & $\begin{array}{l}7.4 \\
*\end{array}$ & 7.5 & 11.2 & 0.7 & 0.6 & 0.1 & 1.9 & 3.8 & 2.7 & 6.6 & $\begin{array}{l}0.4 \\
*\end{array}$ & 7.8 & & * & * & ${ }^{03}$ & ${ }^{62}$ & * \\
\hline & & & 1.2 & 3.0 & 2.2 & 8.1 & 14.4 & 1.9 & 7.9 & 12.81 & 10.9 & 4.1 & 8.0 & 1.7 & 6.8 & 7.7 & 8.9 & 1.8 & 0.9 & 0.2 & 2.2 & & & & & & & & & & & 127 \\
\hline
\end{tabular}




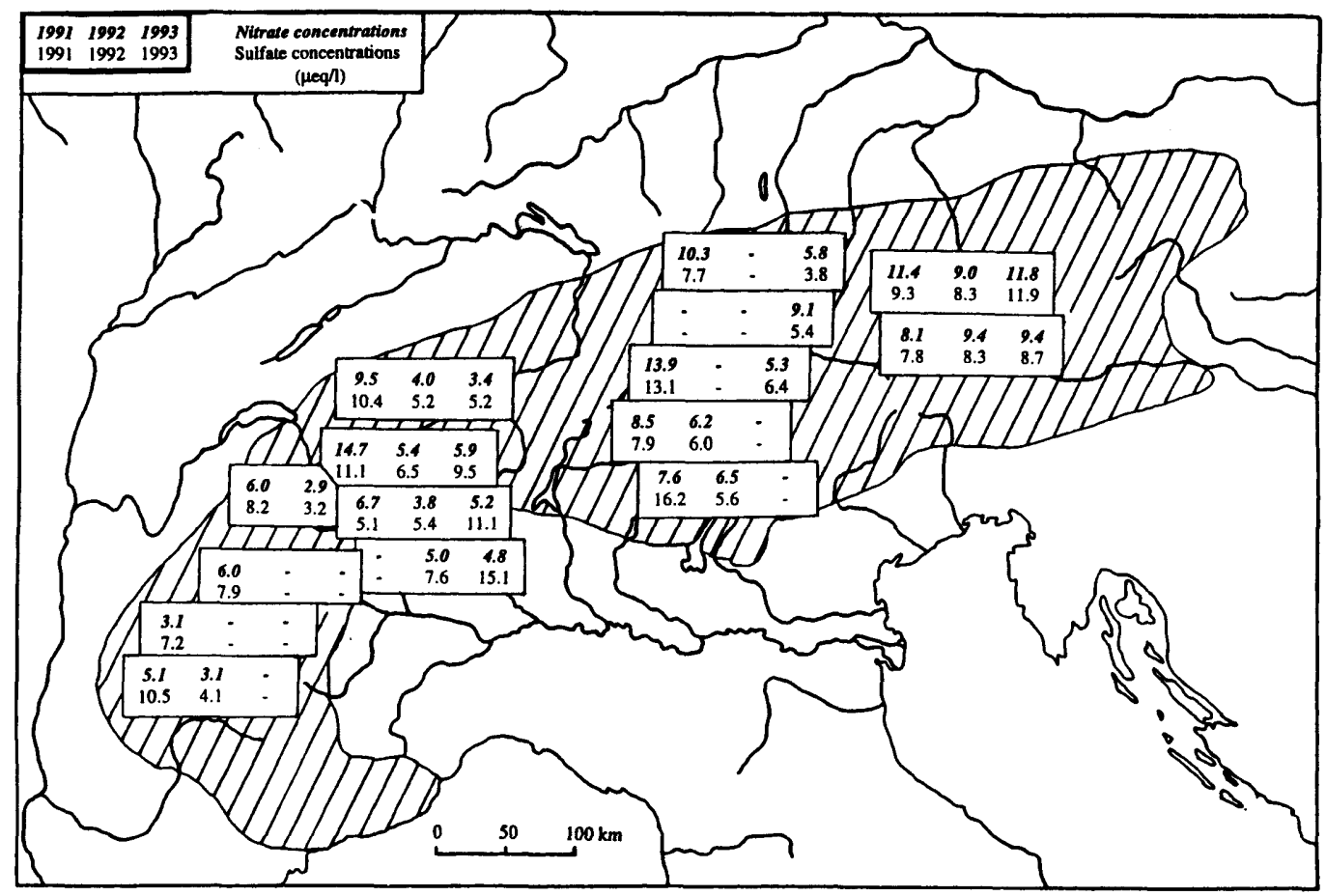

Fig. 2. Weighted mean nitrate and sulfate concentrations $(\mu \mathrm{eq} / 1)$ of the snow cover at the sampling sites at the end of the accumulation period in 1991, 1992 and 1993.

seasonal contrast is caused by differing meteorological conditions: in winter trace gases and particulate matter are not easily mixed through the then rather stable lower troposphere, and up-slope winds are practically absent. Thus substances emitted at ground level cannot reach the high elevation sites. Furthermore, some natural sources are reduced while snow covered or seasonally inactive, which is particularly true for biogenic ammonium (Maupetit et al., 1995).

In spring time, the receeding snow cover and the thriving vegetation open new sources from which trace substances are lifted up in convection and slope winds into a growing mixed layer of the lower atmosphere. The decrease from high autumn concentrations of about $20 \mu \mathrm{eq} / 1$ for nitrate, sulfate and ammonium down to a few $\mu \mathrm{eq} / 1$ during the winter months was found in many cases. An early March profil at Breithorn is given as an example in Fig. 4. The sharp change from low winter concentrations to high ones in spring is obvious in the concentration profile of the snowcover at Colle Vincent (Fig. 5). The increase was even more pronounced due to heavy dustfall occurring April 27, 1993 (snow layer at a depth of about $50 \mathrm{~cm}$ water equivalent). However, the difference from winter to spring concentrations need not be as clear as could be seen in Figs. 4, 5. At Hintereisferner in April 1993 (Fig. 6), for instance, varying but generally low concentrations in winter snow steadily increased to concentrations of 30 to $40 \mu \mathrm{eq} / 1$ in snow layers that could be attributed to March. The uppermost part of the snowpack again showed low ionic concentrations similar to that of winter.

An almost opposite course of the concentration profile was measured at Laaser Ferner in May 1991 (Fig. 7). Indeed concentrations decreased from mid-October to November, but the highest mean ionic concentrations of the total snowpack occurred in the winter layer at a depth of 18 to $43 \mathrm{~cm}$ W.E. (water equivalent).

The different shapes of these concentration profiles demonstrate that the term "winter snow" is not necessarily associated with low ionic concentrations of a few $\mu \mathrm{eq} / 1$ and that the transition 


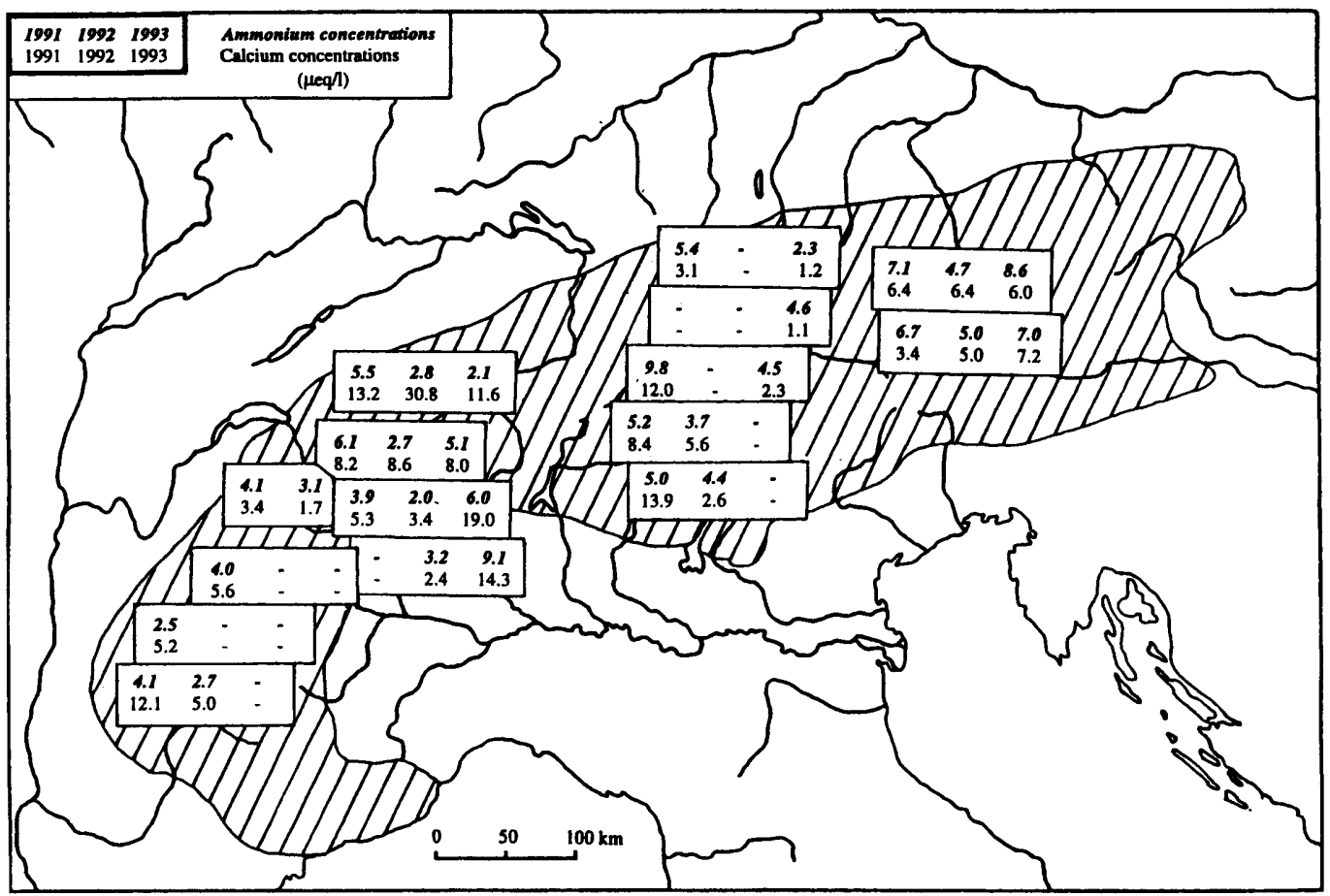

Fig. 3. Weighted mean ammonium and calcium concentrations $(\mu \mathrm{eq} / 1)$ of the snow cover at the sampling sites at the end of the accumulation period in 1991, 1992 and 1993.

from low to high concentrations is reversible and need not be simultaneously at all sites. Thus no statistical method to define snow deposited during winter (e.g., as snow with concentrations lower than $20 \%$ of the March concentrations) will provide satisfactory results when applied to a data set like the SNOSP data. Introducing a fixed day to separate winter from spring snow at all sites was not justifiable either: due to differing weather conditions and elevation one sampling site may already lie within the mixing layer, whereas others may still be situated well above it. No objective and generally practicable criteria could thus be found to characterize winter and spring snow and it was therefore up to the individual working groups within SNOSP to attach snow layers to winter and spring.

\subsection{Spring to winter ratios}

The basic difference between winter and spring snow was one of the reasons for sampling snow twice each winter half year in the SNOSP pro- gram. Since ion concentrations showed a high variability for all sites and years, mean concentrations were calculated from six selected sampling sites (Table 4), in order to derive the range of this seasonal variation. The main criterion for a site to be selected was a complete data set for the years 1991 and 1992, and of course, that the layers of winter and spring snow could be clearly distinguished by the respective working group, responsible for the site.

In Table 4, the concentrations of $\mathrm{NO}_{3}^{-}, \mathrm{SO}_{4}^{=}$, $\mathrm{NH}_{4}^{+}$and $\mathrm{Ca}^{++}$are given for each three stations in the Western and Eastern Alps, respectively. Winter is represented by October to the end of February, and spring by March to May. The ratios of spring to winter concentrations showed a high variability as did all ion concentrations. They ranged from 1.2 to 2.3 for $\mathrm{NO}_{3}^{-}$and $\mathrm{SO}_{4}^{=}$and from 1.7 to 4.4 for $\mathrm{NH}_{4}^{+}$. The seasonality of $\mathrm{NH}_{4}^{+}$is in general significantly higher than that of nitrate and sulfate. (Note the two exceptions: The ratio of 4.1 for sulfate in the eastern group in 1991 was due to an exceptionally high mean 


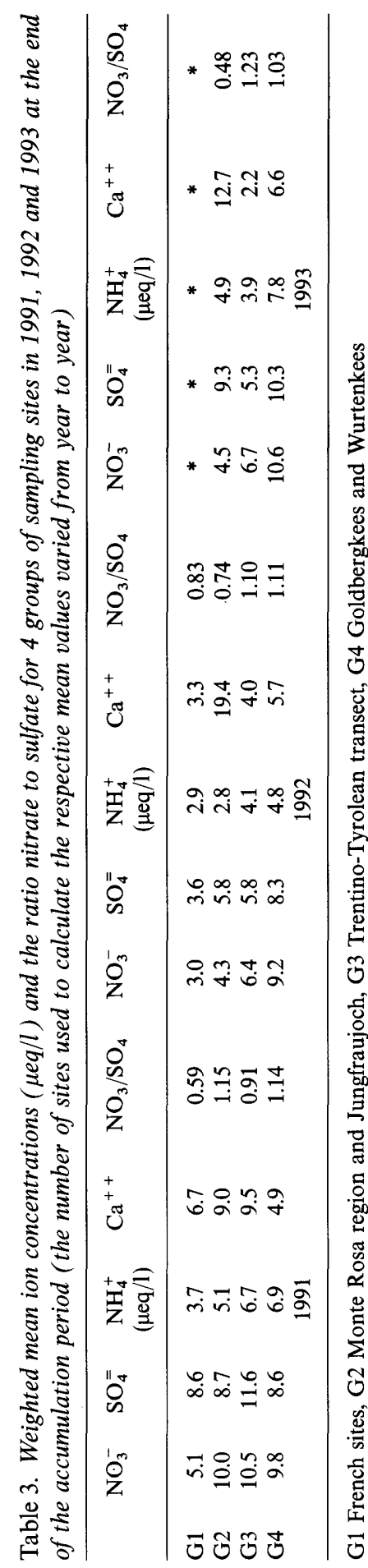

sulfate concentration at Careser glacier caused by Saharan dust fall. The spring to winter ratio of 0.8 for nitrate in 1992 was due to an extremly high nitrate concentration at Goldbergkees.) For calcium, the spring to winter ratios were opposite in the two years 1991 and 1992, displaying again the episodical character of calcium input by mineral dust events as major source. For nitrate, sulfate and ammonium the seasonal contrast expressed by the spring to winter ratios was stronger in the Western than in the Eastern Alps (Table 4). The contrast between the two parts of the Alps seemd to be more pronounced in winter than in spring.

\subsection{Year-to-year variance}

Special events, like dustfall or so called black snow episodes (snow with exceptionally high pollutant concentrations) may strongly influence the year to year variance and the regional distribution pattern of ion concentrations and loads. A change in mean ion concentrations as well as in ionic loads up to a factor of three was frequent for most compounds during the three years of investigation. For $\mathrm{Ca}^{++}$changes could be even twice as high. Nitrate, sulfate and ammonium showed a strong decrease from 1991 to 1992, which did not continue into 1993 in both Western and Eastern Alps. For $\mathrm{Cl}^{-}, \mathrm{Na}^{+}, \mathrm{K}^{+}, \mathrm{Mg}^{++}$and $\mathrm{Ca}^{++}$this decrease was restricted to the Eastern Alps. For the ionic loads this pattern was modified by minor variations in precipitation. It must be clearly stated, that this year to year variance should not be extrapolated as it is based on only three years of observations and is statistically insignificant.

\section{The influence of dust}

Several investigations have shown dust to be an important factor for the chemistry of snowpacks. Wagenbach and Geis (1989) analyzed a 50-year record in an ice core drilled at Colle Gnifetti (Monte Rosa, $4450 \mathrm{~m}$ a.s.l) and attributed 2/3 of the mean mineral dust flux of $60 \mu \mathrm{g} \mathrm{cm}^{-2} \mathrm{yr}^{-1}$ to Saharan dust. Similarly, De Angelis and Gaudichet (1991) found from the analysis of a $70 \mathrm{~m}$ long ice core, drilled in the Mt.Blanc area and covering a period of 30 years that North Africa and the Sahara seem to be a dominating source region for 


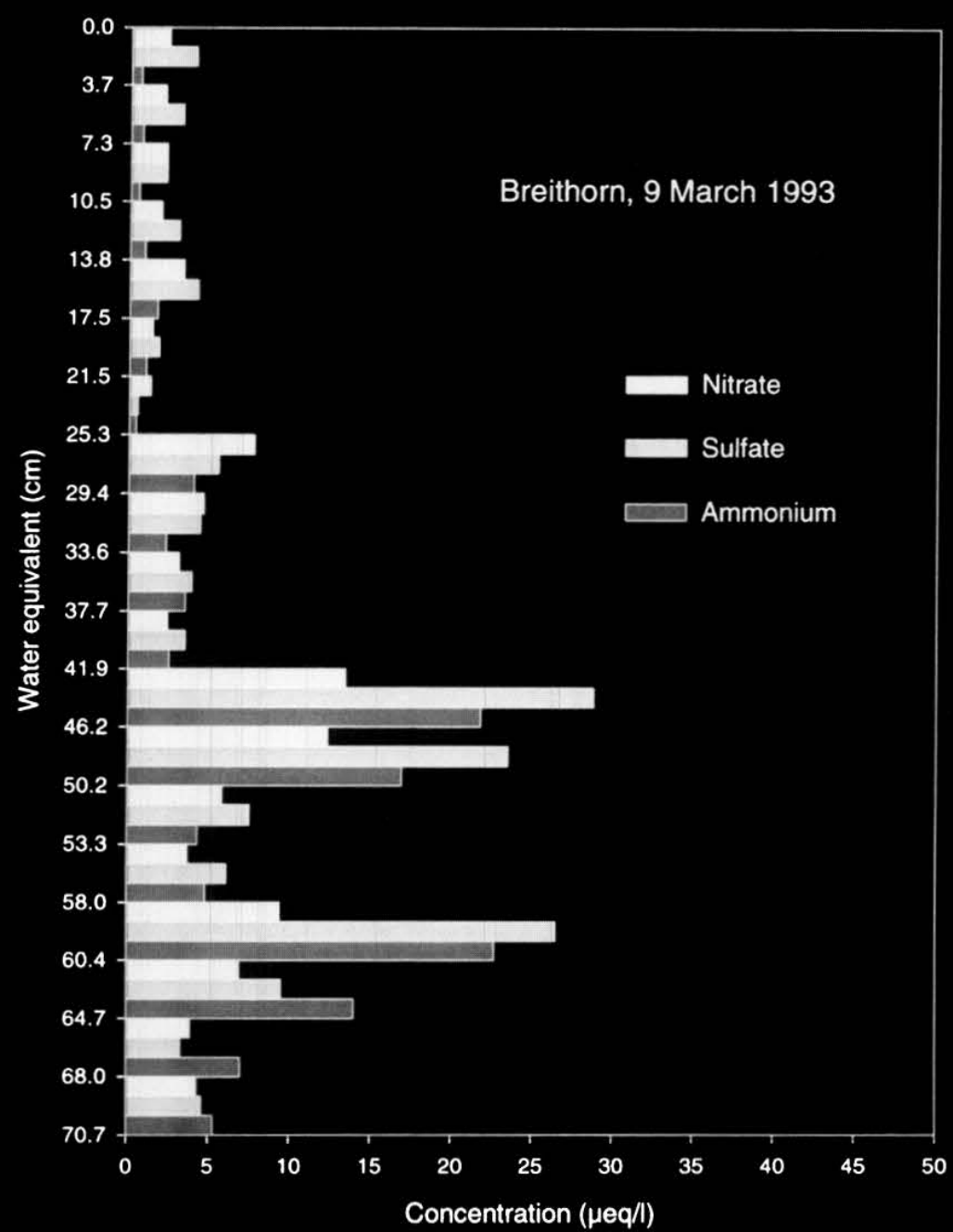

Fig. 4. Vertical profile of ion concentrations ( $\mu$ eq/1) at Breithorn, 9 March 1993.

mineral dust input to the free troposphere over Central Europe. Local sources, on the contrary, contribute only some $30 \%$ of the total calcium input.

Dust containing snow layers show high concentrations of calcium and $\mathrm{HCO}_{3}{ }^{-}$. They may partially or even totally neutralize the accumulated acidity of a snowpack. For instance, one dust layer in the snowcover at Hintereisferner in 1984 raised the total alkalinity determined at two sites of the glacier from negative values of -6 and $-2 \mu \mathrm{eq} / 1$ to positive ones of 1 and $6 \mu \mathrm{eq} / 1$, respectively (Psenner and Nickus, 1986). Wagenbach et al.
(1988) show several examples of mineral dust and associated $\mathrm{pH}$ in the Colle Gnifetti core. Investigations on snow chemistry in the French Alps showed that without all alkaline species the free acidity of a high alpine snowcover would be doubled (Maupetit and Delmas, 1994). The same result was derived from measurements of the wet deposition at Sonnblick-without mineral aerosols the flux of free acidity would be twice as high (Puxbaum et al., 1991).

However, dust does not only increase the input of alkaline species. Dust events can also significantly increase the deposition of sulfate, nitrate and 


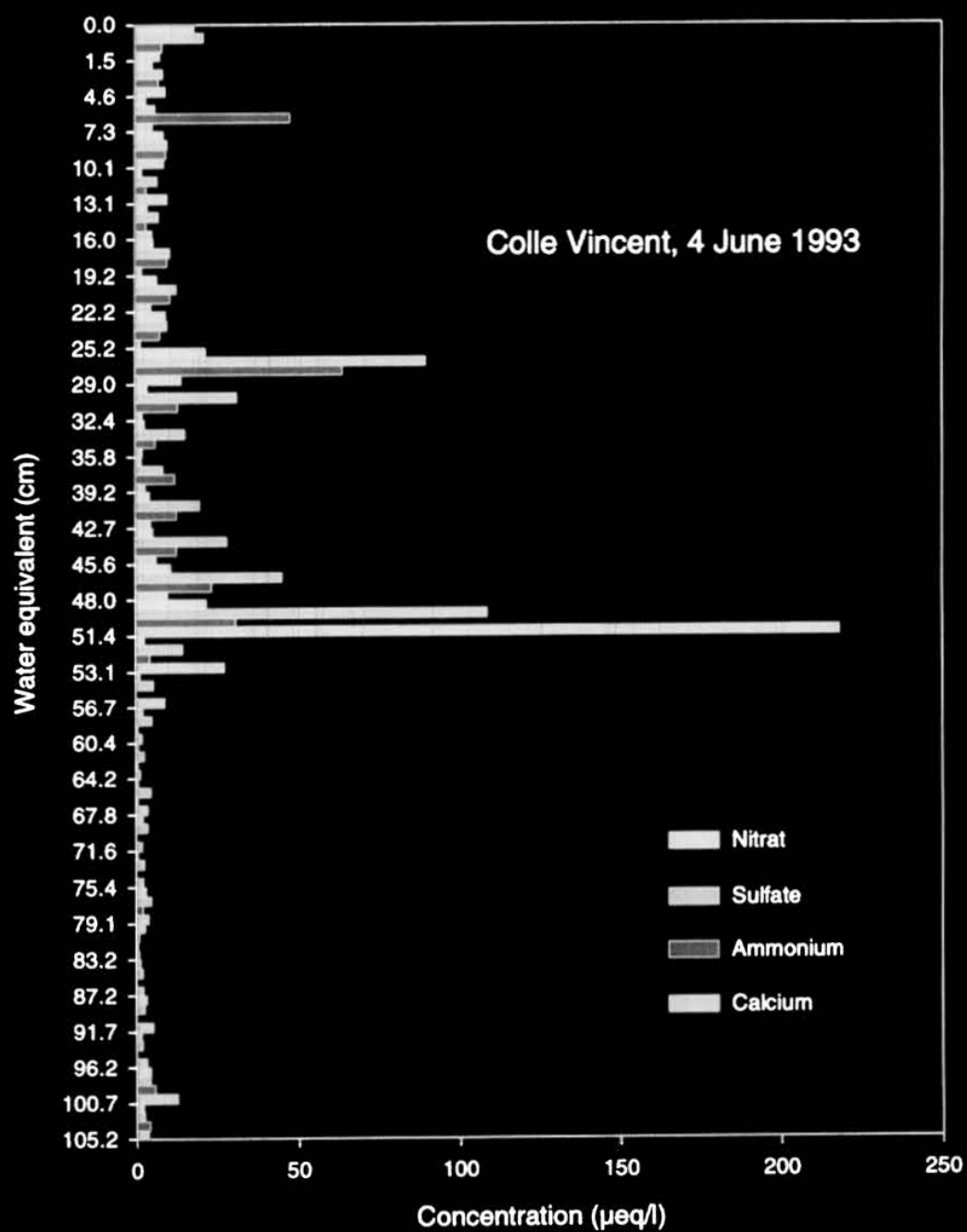

Fig. 5. Vertical profile of ion concentrations ( $\mu$ eq/1) at Colle Vincent, 4 June 1993.

ammonium (Maupetit, 1992). Calcite-rich particles in Saharan dust can react with $\mathrm{SO}_{2}$ or $\mathrm{H}_{2} \mathrm{SO}_{4}$ in the atmosphere, and to a lesser extent also with $\mathrm{HNO}_{3}$ or $\mathrm{NO}_{2}$. Part of the ammonium in snow layers with dust may originate from ammonium-sulfate aerosol in the atmosphere. Impaction on the larger mineral aerosol particles and neutralization reactions with alkaline dust may increase the ammonium concentration of these layers (Maupetit and Delmas, 1994).

Dust events occurred episodically and with varying intensity during SNOSP. Their possible importance for the chemistry of a snowpack shall be demonstrated by 2 examples. The high contri- bution of a dust layer to ionic loads could be seen in the snowcover at Colle Vincent, June 1993 (Novo and Rossi, 1994). $70 \%$ of the respective total deposited amount of calcium, magnesium, potassium, sodium and chloride were found in a $10 \mathrm{~cm}$ thick layer with Saharan dust. For sulfate, nitrate and ammonium the relative contribution to total deposition was less - it amounted to $25 \%, 18 \%$ and $12 \%$, respectively. The sulfate concentration measured in this dust layer was ten times higher than the mean of the total snowpack. Respective concentrations of $\mathrm{Cl}, \mathrm{Na}, \mathrm{K}, \mathrm{Mg}$ and $\mathrm{Ca}$ even reached the 20 to 30 fold value of the mean concentrations (Fig. 5). 


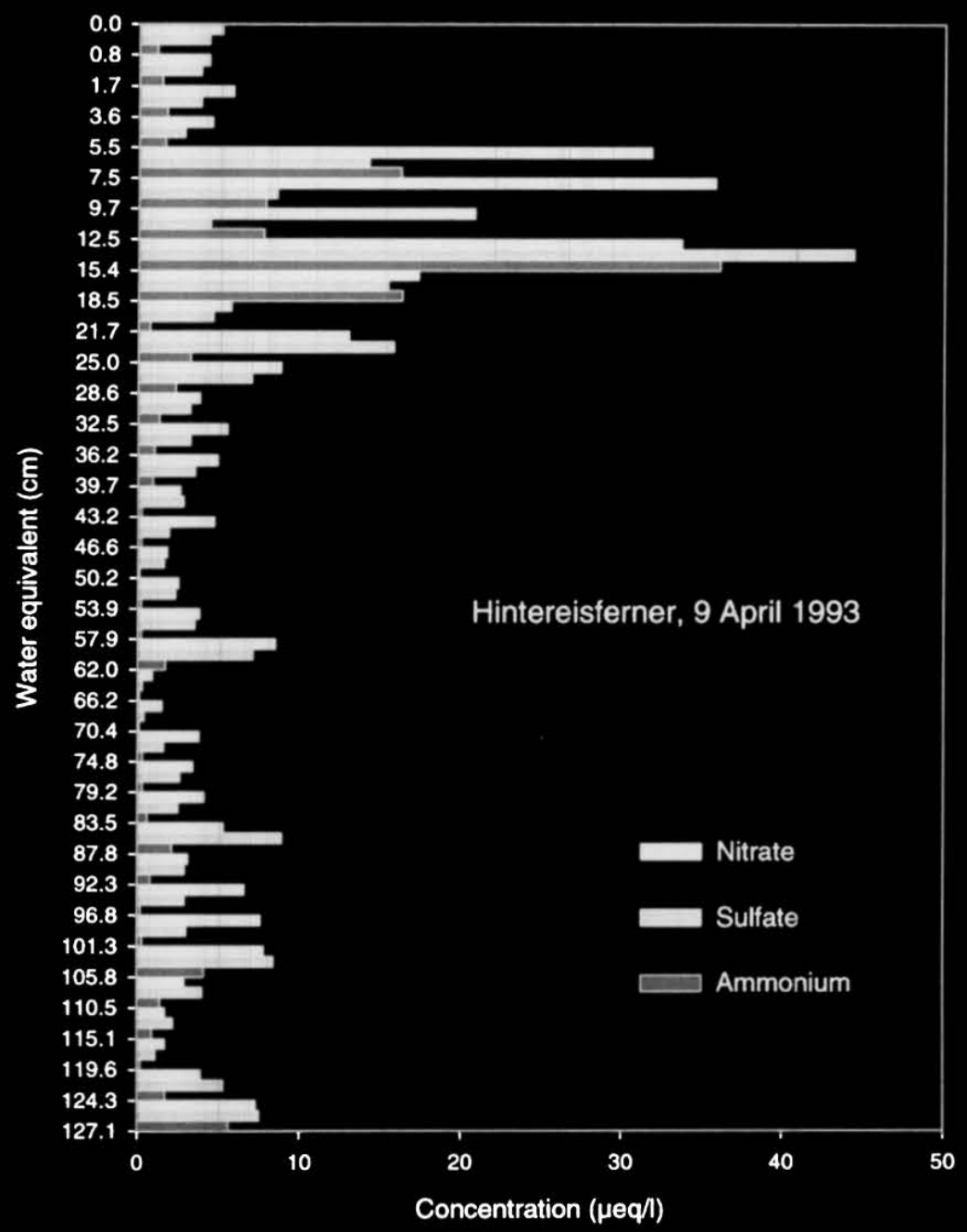

Fig. 6. Vertical profile of ion concentrations ( $\mu \mathrm{eq} / \mathrm{l})$ at Hintereisferner, 9 April 1993.

A similar relation between the ionic concentrations of a dust containing snowlayer and the mean of the complete snowpack was found at Jungfraujoch (Schwikowski et al., 1995) where a dust event on March 20-23, 1990, had caused a calcium concentration of $350 \mu \mathrm{eq} / 1$, which was about 30 times the mean value.

\section{Summary and conclusions}

The foremost goal of SNOSP was to establish the typical spatial and seasonal pattern of the concentration and total deposition of the major atmospheric ions in the high alpine snow cover. The seasonal contrast of concentration in the snow was strongest for ammonium which is closely connected to agriculture and the natural growing cycle, and it was weakest for calcium which seemed to be deposited primarily in local and Saharan dust events. In agreement with the atmospheric circulation patterns, a slightly higher incidence of dust input from the Sahara was observed in spring. Following the peak concentrations reached in the spring and early summer precipitation, acidity decreases when ions are eluted from the mature snow pack by meltwater. In addition the amount of alkaline species in snow layers with mineral 


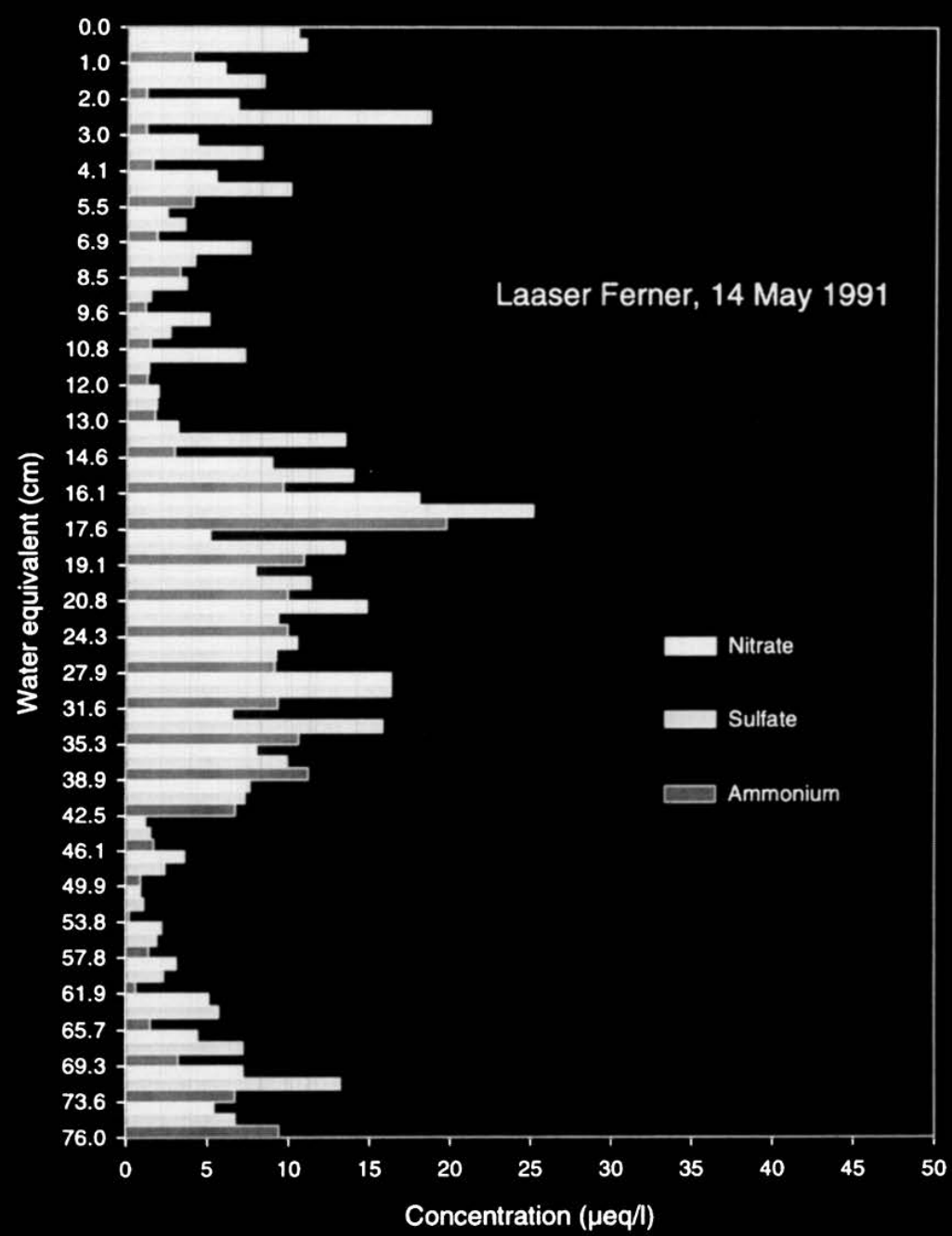

Fig. 7. Vertical profile of ion concentrations ( $\mu \mathrm{eq} / 1)$ at Laaser Ferner, 5 May 1991.

dust is an important buffer for the free acidity accumulated in the total snow pack. Both effects, the elution of ions by meltwater and the dust deposition "purify" the snow to the extent that the glacier ice into which it gradually transforms is less acid than the original precipitation.

The large-scale geographical distribution of ions in the snow pack was clearly dominated by a west-to-east increase in concentration of most species, whereas in the total ionic deposition this increase was less developed or partly reversed by a generally west-to-east decrease in the water equivalent of winter and spring snow cover. The east-west differences in respective mean concentra- tions of nitrate, sulfate and ammonium ranged between 2 and $5 \mu \mathrm{eq} / \mathrm{l}$. The eastern and western part of the Alps differed also in the mean sulfate to nitrate ratio. Sulfate was the predominating compound in the west, whereas at the eastern sampling sites nitrate concentrations were generally higher compared to sulfate. Similarly the chloride to sulfate ratio was twice as high in the east than in the west.

There were some indications that sampling sites in the dry interior of the Alps would not experience significantly less acid deposition than those situated on the exterior slopes, but high local and year-to-year variability may have masked the long 
Table 4. Water equivalent $(\mathrm{cm})$ and ion concentrations ( $\mu$ eq/l) for selected sites in the western eastern Alps, separated into winter and spring snow, respectively, mean values for the western and eastern group and ratio east to west (winter: October to February, spring: March to May)

\begin{tabular}{|c|c|c|c|c|c|c|c|c|c|c|c|}
\hline & & \multicolumn{2}{|c|}{ W.E. $(\mathrm{cm})$} & \multicolumn{2}{|c|}{$\mathrm{NO}_{3}^{-}$} & \multicolumn{2}{|c|}{$\mathrm{SO}_{4}^{=}$} & \multicolumn{2}{|c|}{$\mathrm{NH}_{4}^{+}$} & \multicolumn{2}{|c|}{$\mathrm{Ca}^{++}$} \\
\hline & & 1991 & 1992 & 1991 & 1992 & 1991 & 1992 & 1991 & 1992 & 1991 & 1992 \\
\hline \multirow[t]{2}{*}{ Grave (1) } & Winter & 86 & 102 & 3.2 & 2.8 & 3.9 & 3.8 & 1.1 & 1.5 & 2.9 & 3.4 \\
\hline & Spring & 109 & 73 & 6.6 & 3.6 & 15.7 & 4.5 & 6.5 & 4.4 & 19.4 & 7.3 \\
\hline \multirow[t]{2}{*}{ Breithorn (2) } & Winter & 70 & 37 & 4.6 & 2.6 & 4.2 & 7.0 & 3.4 & 1.1 & 1.8 & 1.2 \\
\hline & Spring & 25 & 20 & 12.5 & 5.9 & 6.9 & 7.4 & 5.2 & 3.4 & 9.1 & 2.3 \\
\hline \multirow[t]{2}{*}{ Jungfrauj. (3) } & Winter & 37 & 178 & 4.6 & 3.0 & 4.1 & 4.5 & 1.1 & 1.1 & 21.3 & 36.5 \\
\hline & Spring & 64 & 81 & 12.4 & 6.3 & 14.0 & 6.7 & 8.1 & 6.8 & 8.5 & 18.2 \\
\hline \multirow{2}{*}{ Careser (4) } & Winter & 80 & 45 & 4.0 & 4.9 & 9.2 & 5.1 & 3.0 & 2.3 & 8.9 & 2.5 \\
\hline & Spring & 32 & 41 & 18.4 & 8.3 & 31.8 & 6.2 & 9.4 & 6.7 & 24.7 & 2.7 \\
\hline \multirow[t]{2}{*}{ Laaser F. (5) } & Winter & 36 & 43 & 4.3 & 4.8 & 6.6 & 5.4 & 2.7 & 2.4 & 14.1 & 5.2 \\
\hline & Spring & 40 & 31 & 9.1 & 8.1 & 10.3 & 7.4 & 6.7 & 5.5 & 4.1 & 6.8 \\
\hline \multirow{2}{*}{ Goldbergk.(6) } & Winter & 64 & 131 & 11.0 & 10.5 & 6.9 & 7.7 & 4.3 & 4.4 & 4.3 & 7.4 \\
\hline & Spring & 39 & 31 & 12.1 & 2.5 & 13.1 & 10.8 & 11.8 & 5.7 & 9.7 & 2.1 \\
\hline \multirow[t]{3}{*}{ West (1-3) } & Winter & 64 & 106 & 4.0 & 2.9 & 4.1 & 4.6 & 1.9 & 1.2 & 6.0 & 21.7 \\
\hline & Spring & 66 & 58 & 9.2 & 5.1 & 14.0 & 5.9 & 6.8 & 5.4 & 14.6 & 11.8 \\
\hline & Spr./Win. & 1.0 & 0.5 & 2.3 & 1.8 & 4.1 & 1.3 & 3.5 & 4.4 & 24.0 & 0.5 \\
\hline \multirow[t]{3}{*}{ East (4-6) } & Winter & 60 & 73 & 6.6 & 8.2 & 7.9 & 6.7 & 3.4 & 3.6 & 8.3 & 6.0 \\
\hline & Spring & 37 & 34 & 12.8 & 6.5 & 17.5 & 7.9 & 9.2 & 6.0 & 12.0 & 3.8 \\
\hline & Spr./Win. & 0.6 & 0.5 & 2.0 & 0.8 & 2.2 & 1.2 & 2.7 & 1.7 & 1.4 & 0.6 \\
\hline \multirow{2}{*}{ East/West } & Winter & 0.9 & 0.7 & 1.7 & 2.9 & 1.9 & 1.5 & 1.8 & 2.9 & 1.4 & 0.3 \\
\hline & Spring & 0.6 & 0.6 & 1.4 & 1.3 & 1.3 & 1.4 & 1.4 & 1.1 & 0.8 & 0.3 \\
\hline
\end{tabular}

term average precipitation pattern. A comparison of neighbouring, central sites like those in the Trentino-Tyrolean transect (group 3) revealed that acid deposition is more variable than precipitation at scales of less than $100 \mathrm{~km}$ distance.

\section{Acknowledgements}

The snow sampling program SNOSP was part of ALPTRAC, a subproject to EUROTRAC. It was funded by CNRS and Ministère de l' Environnement (France), Swiss National Science Foundation and Schweizer Bundesamt für Bildung und Wissenschaft (Switzerland), German Ministry for Research and Technology (Germany), Biologisches Landeslabor der Autonomen Provinz Bozen (Italy), Bundesministerium für Wissenschaft und Forschung, Bundesministerium für Umwelt and Fonds zur Förderung der wissenschaftlichen Forschung (Austria).

\section{REFERENCES}

De Angelis, M. and Gaudichet, A. 1991. Saharan dust deposition over Mont Blanc (French Alps) during the last 30 years. Tellus 43 B, 61-75.

Johannessen, M. and Henriksen, A. 1978. Chemistry of snow meltwater: Changes in concentration during melting. Water Res. Research 14, 615-619.

Kromp-Kolb, H., Schöner, W. and Seibert, P. 1993. ALPTRAC data catalogue. EUROTRAC, Intern. Scientific Secretary, Garmisch-Partenkirchen.

Maupetit, F. 1992. Chimie de la neige de tres haute altitude dans les Alpes Francaises. $\mathrm{PhD}$ Thesis, Paris 7 University.

Maupetit, F. and Delmas, R.J. 1994. Snow chemistry of high altitude glaciers in the French Alps. Tellus 46 B, 304-324.

Maupetit, F., Wagenbach, D., Weddeling, P. and Delmas, R.J. 1995. Seasonal fluxes of major ions to a high altitude cold alpine glacier. Atmos. Environm. 29, 1-9. Neftel, A., Sigg, A. and Zürcher F. 1987. Acid deposition in a snow field at $2500 \mathrm{~m}$ a.s.l. in Switzerland. In: Physico. chemical behaviour of atm.pollutants, Air Pollution Res. Report 2. Reidel, Dordrecht, 500-510.

Nickus, U. and Kuhn, M. 1993. Local variance of acid deposition. In: Proceedings of EUROTRAC Symp.'92 (eds.: P.M. Borell). The Hague, SPB Acad. Publ., $770-773$. 
Nickus, U. and Kuhn, M. 1994. Ion chromatographic determination of anions and cations at ultra-low concentrations in Alpine snow. J.Chromatogr. A 671, 225-229.

Novo, A. and Rossi G.C. 1994. 1993 Alpine snow chemistry campaign on the Colle Vincent and Careser. EUROTRAC Annual Report 1993, 22-28.

Psenner, R. and Nickus, U. 1986. Snow chemistry of a glacier in the Central Eastern Alps (Hintereisferner, Tyrol, Austria). Zeitschrift für Gletscherkunde und Glazialgeologie 22, 1-18.

Psenner, R., Arzet, K., Brugger, A., Franzoi, J., Hiesberger, F., Honsig-Erlenburg, W., Horner, F., Müller, W., Nickus, U., Pfister, P., Schaber, P. and Zapf, F. 1988. Versauerung von Hochgebirgsseen in kristallinen Einzugsgebieten Tirols und Kärntens. Wasserwirtschaft, Wasservorsorge. BM Land- und Forstwirtschaft, Wien.

Puxbaum, H. 1990. The high alpine aerosol and snow chemistry study. In: The Proceedings of EUROTRAC Symp.'90 (ed. P.M. Borell). The Hague, SPB Acad.Publ., 53-54.

Puxbaum, H., Kovar, A. and Kalina M. 1991. Chemical composition and fluxes of wet deposition at elevated sites (700-3105 m a.s.l.) in the Eastern Alps. NATO ASI Series G 28, 273-297.

Ronseaux, F. and Delmas, R.J. 1988. Chemical deposition of bulk atmospheric deposition to snow at $\mathrm{Col}$ de la Brenva (Mt.Blanc Area). In: Acid deposition at high elevation sites (ed. M.H. Unsworth and D. Fowler). Kluwer, Dordrecht, 491-510.

Schöner, W., Puxbaum, H., Staudinger, M., Maupetit, F. and Wagenbach, D. 1996. Spatial variability in the chemical composition of the snowcover at high elevated sites. Theor. Appl. Climatol., in press.

Schwikowski, M., Seibert, P., Baltensperger, U. and Gäggeler, H.W. 1995. A study of an outstanding Saharan dust event at the high-alpine site Jungfraujoch, Switzerland. Atmos. Environm. 29, 1829-1842.

Schwikowski, M., Novo, A., Baltensperger, U., Delmas, R., Gäggeler, H.W., Kasper, A., Kuhn, M., Maupetit, F., Nickus, U., Preunkert, S., Puxbaum, H., Rossi, C.G., Schöner, W. and Wagenbach, D. 1996. Intercomparison of snow sampling and analysis within the alpine-wide snow pack investigation (SNOSP). Water, Air, and Soil Pollution, in press.

Wagenbach, D., Münnich, K.O., Schotterer, U. and Öschger, H. 1988. The anthropogenic impact on snow chemistry at Colle Gnifetti, Swiss Alps. Annals of Glaciology 10, 183-187.

Wagenbach, D. and Geis, K. 1989. The mineral dust record in a high altitude alpine glacier (Colle Gnifetti, Swiss Alps). In: Paleoclimatology and paleometeorology: modern and past patterns of global atmospheric transport (ed. M. Leinen and M. Sarnthein M). Kluwer Acad.Publ., 543-564. 